\title{
Art Museum Dining: The History of Eating Out at the Art Gallery of Ontario
}

Irina Mihalache*

\begin{abstract}
Using archival materials from the Art Gallery of Ontario (AGO), this article recreates the culinary history of the art museum and advocates for the inclusion of food in the literature on art museum history and practice. The AGO, like many other North American art museums, has a rich culinary history, which started with dining events organized by volunteer women's committees in the 1940s. These culinary programs generated a culinary culture grounded in gourmet ideologies, which became the grounds for the first official eating spaces in the museum in the mid-1970s. Awareness of the museum's culinary history offers an opportunity to liberate the museum from prescriptive theoretical models which are not anchored in institutional realities; these hide aspects of gender and class which become visible through food narratives.
\end{abstract}

Keywords: Art museum restaurants, culinary programming, women's committees, multisensorial museums, Art Gallery of Ontario

\section{Introduction}

A 2006 New York Times article opined, not quite accurately, that 'fifty years ago, the idea that a museum would put that much thought into what to feed visitors would have seemed absurd. When the Metropolitan Museum of Art (the Met) opened its first large cafeteria in 1954, it did so grudgingly. Museums were for art, science and history. Restaurants were for eating'. ${ }^{1}$ A similar 'myth' about museum dining comes from Andrew McClellan (2008: 193), who wrote that 'a time traveller from the 1950s would surely be astonished to discover that it is now possible in our museums to eat (and eat well), shop, see a film, hear a concert, mingle at "singles night", and attend a corporate function or wedding reception'. These stories, which are representative, suggest that eating in has a marginal role in museum histories, with only a recent emergence of the museum restaurant as a significant space.

Such stories have a series of consequences, which will be challenged in this article. The explosion of communication regarding food in blogs, social media, print, and television in the last two decades has increased the visibility of museum restaurants, with a focus on spectacular dining prepared by celebrity chefs (Mihalache forthcoming 2017). Extensive coverage of this rather privileged genre of museum dining contributes to a myth of newness. The abundance of stories about new museum restaurants results in the absence of an accurate history of art museum restaurants. For example, the Met's restaurant opened prior to 1905 and is mentioned in the first issue of the Bulletin ${ }^{2}$. The myth of newness perpetuates a lack of concern for other instances of eating in museums, which often precede the restaurant, such as culinary events planned by volunteer women's committees in art museums since the 1920s (Mihalache 2016a). In museum studies scholarship, dining is relatively absent and often interpreted as a sign of increased commercialism of museums (Duncan 1995; McClellan 2008; Sylvester 2009). And even when museum professionals reflect on museum restaurants, as is the case of a special issue on "Food in the Museum" of Museum, they pay attention to recent trends with little connection to the history of eating in museums. ${ }^{3}$ 
This article positions the museum restaurant as a significant social and cultural space, which, like the late nineteenth century museum and department store, was an institution of modernity in its own right. While the restaurant is the most visible eating space in the art museum, its presence is connected to other forms of museum dining developed by volunteer women's committees. Several large art museums, such as the Met, featured restaurants as early as the 1900s, but many other institutions did not develop official eating spaces until the 1950 s and even later. Despite the lack of an official eating space, these art museums were active producers of culinary events. Within this framework, the article advocates for the inclusion of the restaurant in art museum histories and provides a model for recreating a restaurant's history using the Art Gallery of Ontario (AGO) ${ }^{4}$ in Toronto as an example. One goal of this article is to demonstrate the relation between the work with food of women's committees and the establishment of official restaurants. AGO's culinary history, similar to that of other art museums, would be incomplete without reflections on women's work.

Writing culinary histories with attention to institutional specificities and recognition of the volunteer work of women's committees (re)integrates marginal communities and yields agency to domestic culinary knowledge in art museum histories. Museums' culinary stories elucidate gender and class hierarchies which both confirm and challenge the art museum's elitist positioning within the community. The article aligns itself with Danielle Rice's (2003: 7778) call for a 'useful middle ground' between theory and practice which would challenge the 'image of the museum as a monolithic representative of elite taste and institutional power'. The museum restaurant, analyzed as 'platform for much of our social activity' and a product of 'the changing nature of sociality' (Finkelstein 2014: viii) is an ideal site to trouble such representations, as it documents forms of sociability performed in museums but sometimes distanced from the museum's core functions.

This article first positions the restaurant as an institution of modernity which constructed modes of being in public, alongside other institutions. The restaurant and other culinary programs, afforded degrees of freedom which were less possible inside vision-centred (Bennett 1995) cultural institutions. While being institutions on their own, restaurants were also incorporated into larger these cultural complexes. The Art Gallery of Ontario represents the case study of this investigation, which focuses on the 'gourmet' period in the work of women's committees, the 1960s and early 1970s, which concluded with the opening of AGO's first official restaurant. Since the 1970s, AGO's restaurants have evolved from a type of gourmet site based on domestic knowledge and a preference for Canadian ingredients, which was visible in culinary programming done by women's committees, to a global bistro fusion aligned with high cuisine. An exploration of the museum's culinary history highlights the modes in which eating has shaped the museum.

This study used two archival collections from the AGO's Edward P. Taylor Library and Archives: the women's committees archival materials (1940s-1970s), which are extensive and contain bulletins, annual reports, calendars of events, correspondence, meeting notes, exhibition files and restaurant menus; and the Dining Services files (1970s - 1990s), which contain limited information about the various restaurants. To supplement archival documents, media sources, annual reports and AGO's website have been consulted as well.

\section{Restaurants as Institutions of Modernity and Practices of Eating in Art Museums}

\section{Restaurants in Art Museums: A Curious Absence}

There are numerous intersections between food and museums (Levent and Mihalache 2016), some of which are better documented than others. Topics such as food as a subject of artistic creation (Walker 1999; Barnes and Rose 2002; Malaguzzi 2008), food's presence in contemporary art (Kirshenblatt-Gimblett 1999; Whittall 2016; Bottinelli and Valva forthcoming 2017) and historic cooking (Moon 2016) have been established as significant in several academic areas. However, a survey of the main literature in museum studies (Carbonell 2004, Watson 2007, Karp et al. 2007, Macdonald and Leahy, 2016) suggests that the restaurant is not seen as a significant space to be studied in relation to the history and practices of art museums. Spaces that have a commercial purpose - the restaurant and the gift shop - are 
brushed off as profit makers for the museum and sometimes seen as undesirable signs of the hyper-commercialism of culture. Noting the 'crass commercialism' of today's art museums, Christine Sylvester (2009: 2 \& footnote) wrote that 'museum restaurants add to the bazaar effect...and even the most pedestrian of museum restaurants can return up to 25 percent of their gross revenues to the museum'. A little more generous is Amy Kaufman and Chris Lorway's (2010: 129) perspective on the museum restaurant as an important component of museum planning and social space which 'functions more as a public service than a revenue generator'. However, the restaurant is presented as a passive space, where visitors take a break, rest and recharge, and not as a space with interpretation and education potential (Mihalache 2016b). A brush off of the restaurant as purely a space for consumption would deny the relevance of food studies literature which positions the restaurant as a significant space (Berriss \& Sutton 2007; Finkelstein 2014; Leschziner 2015; Ray 2016).

\section{Restaurants and Museums: Different Models of Modernity}

The restaurant emerged out of similar social, political and economic contexts - industrialization, capitalism, emergence of mass entertainment, development of urban politics - as other institutions intended to regulate publics. By looking at the 'genealogy' of museums, fairs and exhibitions, Tony Bennett (1995: 6) analyzed the 'transformation in the arrangement of the cultural field in the nineteenth century' in light of new concerns for social management. The concerns that Bennett 1995: 6-7) raises in relation to the functions of these new institutions - 'reshaping general norms of social behaviour'; controlling an 'undifferentiated mass public'; and sustaining the project of a participatory democracy, with equal access to all citizens - could also apply to the restaurant and its many iterations. In Boston, for example, Erby (2016: xxi) identified 'elite hotel dining rooms, male-dominated eating houses, ladies' dining rooms and confectioners, and mixed-gender cafes'. Richard Pillsbury (1990: 24) wrote of several others: the tavern, the oyster house, the coffee shop, the tea garden and the restorator, a precursor to the restaurant as we know it. These public eating spaces confronted the modern citizen with new practices of sociability, rooted in novel forms of gender and class distinction, not unlike those encountered inside museums. In a public sphere rearranged through the work of new institutions and new modes of sociability, these restaurants shared publics with museums, implying a transference of practices which is worth investigating.

Bennett (1995: 6) does not include the restaurant among the institutions involved in the practice of 'showing and telling: that is of exhibiting artefacts and/or persons in a manner calculated to embody and communicate specific cultural meanings and values'. Tony Bennett (1995: 19) discovered that, starting with the late eighteenth century, culture was thought of as 'useful for governing' and 'fashioned as a vehicle for the exercise of new forms of power'. The museum was to play a crucial role in projects of population control, as it was seen by city officials and lawmakers as 'rational recreation' which could channel elite culture to correct some unruly habits of the lower classes. For example, drunkenness was one of the social problems that required intervention. Rather than a close policing of the ale-house, a place demonized for aggravating habits of drinking, the museum could produce, through cultural means 'individuals who did not want to besot themselves in ale-houses' (Bennett 1995: 20). While the restaurant had a better reputation than the ale-house and was accessible to women, spaces for food consumption were perceived more commonly as problems rather than possible solutions to what public officials at the time identified as social issues. Escaping the net of recreation that was approved by these officials afforded eating establishments a form of agency which engaged public and private forces.

Writing about Parisian cafés in the late eighteenth century, Rebecca Spang (2001: 84) invoked the Habermasian concept of the public sphere, which suggested that 'these innovative semi-public institutions served as meeting places for individuals from varied socioeconomic backgrounds, all united by their capacity for rational dialogue'. Aspace of political effervescence and public debate, yet accessible only to men, the café was falsely imagined as a space of consensus when, added Spang (2001: 86), 'interaction in the new common spaces would not necessarily have to lead to the discovery of shared opinions or enlightened universals' intended to advance the common good. Spang gave the restaurant as a counterexample to the 
idealized café, as the restaurant 'addressed the common good by means of the individual and the particular' (Spang 2001: 86). The individual customer was part of a collective experience in the restaurant but 'once seated at the table, one was left to confront one's own sensibility' (Spang 2001: 86), challenging the Habermasian framework which assumed that 'disagreement was to be settled through the egalitarian process of enlightened communication' (Spang 2001: 84). Observing eating out practices as a product of 'shared social codes' (Spang 2001: 86) while at the same time acknowledging individual preferences outside of the prescribed civilizing norms of the space provides a model for analysing other new institutions in the nineteenth century cultural field.

Writing about the history of public dining in Boston, Kelly Erby (2016: xviii) emphasized the democratization of public culture - 'surely such accessibility signalled the achievement of equality in American society' - in contrast with the 'fragmentation and difference that... increasingly defined America's urban, market-driven society'. Similar to other $19^{\text {th }}$ century institutions of leisure and culture which provided a public space where different social groups could meet, the restaurant enforced existing forms of distinction at the same time as 'crosscut[ing] socioeconomic, gender, racial and ethnic affiliations' (Erby 2016: xix). In the Foucauldian-inspired genealogy of the museum, the institutional model of surveillance based on an exhibitionary complex - 'the custom-built settings in which particular kinds of power/ knowledge relations are produced and brought to bear on those who visit' (Bennett 2015: 4) - assumes that the public willingly participates in the imposed modes of behaviour, with little resistance or ability to interpret museum objects according to a lens other than that facilitated by the institution. Restaurants, which were not seen as allies of surveillance at the same level as museums by public administrators, afforded more freedom to diners. Erby (2016: xvii) uncovered that 'the experience of dining out could provide opportunities for cultural experimentation, transmission and fusion'. Along the same lines, Marc Jacobs and Peter Scholliers (2003: 10) wrote that 'social codes in restaurants were used to exclude and include, but they could also be acquired, interpreted and applied for transgression'. The potential for creativity and transgression comes from the multisensory experience of dining out, which merges taste and smell with elements of spectacle, display and vision.

\section{Beyond Vision Inside Art Museums: Culinary Programming Resists Institutional Practice}

While Tony Bennett revisited the 'exhibitionary complex' (1995) model several times, exploring 'civic seeing' (2006) and, later, the relation between museums and 'governmental assemblages' (2015), the museum was still imagined as a space dominated by vision and experienced by visitors, at the level of sight. Observing the museum as a 'civic institution' involves 'specific regimes of vision' which inform 'both the manner in which things are arranged to be seen and the broader visual environment conditioning practices of looking' (Bennett 2006: 263). This framework leaves very little room for individual agency and for the development of meaningmaking practices in museums which escape the boundaries of the exhibitionary complex. Also, little consideration is given to other experiences which museumgoers can have, which are generated by practices such as eating. While the museum's official functions were indeed to preserve material culture and display artefacts, other practices complicated the vision-centric view of the museum.

Recent work in museum studies (Classen 2007; Candlin 2010; Levent and PascualLeone 2015) provides extensive evidence of multisensory moments in museums, suggesting that "in the wake of this "sensory turn," contemporary museum professionals have started rethinking the multiple restrictions on the use of the senses in the museum' (Levent and Pascual-Leone 2015: xvii).

Reflecting on eating in museums as a social practice with its own history implies an evaluation of the 'interplay of structure and agency, subject and object' (Warde 2016: 33). Systems of class and gender distinction (Bourdieu 1984) and rituals of socialization (Douglas 1972; 1984), specific to the museum environment outline the formation of a cultural field (Bourdieu 1984 ) in the art museum around instances of public food consumption. The earlier forms of museum dining planned by volunteers, including afternoon teas, luncheons with curators and 
balls were not designed to establish a set of practices as a formal restaurant would. If a practice is defined as 'an entity which is "coordinated"' (Warde 2016: 45), food practices in museum lacked such intentional coordination. For example, as many culinary events were planned by volunteers, the identity of each event was often associated with the specific expertise of the cooks, which affected the menu, cooking techniques and decor. Often, selection of dishes depended on the availability of ingredients, many acquired through donations. Such programs were produced at arm's length from the administration and with no financial support from the institution, offering more freedom to their producers.

The traditional pathway towards the development of a practice implies codification and formalization, which require 'serious commitment to the proper conduct of such Practices' (Warde 2016: 45) from communities and organizations. Yet in many art museums, restaurants, the formal spaces for public eating appeared as a result of the informal culinary cultures produced by volunteer groups. The structures of informal eating sometimes collided with the museum's priorities and functions, yet generated a cultural context for the new restaurant. Restaurants developed through the legacy of volunteer committees reproduced certain biases, behaviours and social knowledge deemed important to share.

\section{Women's Committees and Culinary Programming: Crafting an Eating Culture at the Art Gallery of Toronto and Beyond}

\section{Seeking Relevance through Food: The Art Gallery of Ontario's Culinary History}

With origins in 1913, the AGO grew to become one of the largest Canadian art institutions with a collection including, among others, African and Oceanic art, modern and contemporary art, photography, indigenous art, and prints and drawings. Throughout the years, it underwent a series of expansions, each affecting the museum's culinary infrastructure. At the same time as the art museum was expanding, the Grange, the house which constituted the museum's first gallery, continued to function as a historic house museum restored to the 1835-1840 period, where much of the culinary life of the museum would develop. While the museum's first official restaurant, the Grange Court Restaurant, did not open until 1974, as part of a major renovation project, visitors could enjoy plenty of culinary experiences, as early as the mid-1920s, when the Grange's breakfast parlour was set up as a tea room. As a new museum which envisioned itself to be the art hub of the community, the AGT incorporated into its programming several elements of leisure and entertainment, such as music, film, crafts and Christmas parties for children.

While AGT's relevance was constructed by its employees in terms of the uplifting value of art - 'art has been a most important force in the development of every great civilization and the service rendered by the Art Gallery of Toronto to its members and friends should and will be a force of inestimable value to the people of Toronto' (Bulletin 1926: 14) - the realities of making relevance demanded more concrete actions than art's inherent power. ${ }^{5}$ The museum, therefore, became the site of numerous educational initiatives, community outreach campaigns and engaging programming intended to establish a solid bond between the institution and citizens of Toronto. Alongside the curatorial team and the administration, numerous volunteers took charge, from the early days of the museum, of building bridges with Toronto citizens, constantly working to expand the boundaries of the museum's reach. For example, in 1949, the Public Relations Project of the AGT was established to solve the lack of diversity of museum goers, who were identified as a 'relatively specialized group....rather than 'average Canadians'. ${ }^{6}$ In charge with building the museum's relevance were the women's committees, who 'from the mid-1940s until the 1970s...modified the Art Gallery of Toronto to accommodate culinary spaces, adding a culinary infrastructure onto the other functions of the gallery (Mihalache 2016a: 171).

\section{Women's Committees Make Culinary History}

The Women's Committee at the Art Gallery of Toronto (AGT) was founded in 1945 as 'a subsidiary of the Men's Executive' with the aims to 'keep the activities and opportunities 
offered by the Gallery before the public, and to increase the membership to the gallery'. ${ }^{7} \mathrm{~A}$ second organization, the Junior Women's Committee, was formed in 1950 to assist its senior counterpart with specific events. The duties of women's committees included education and public programming for children, youth, and adults; public relations and membership; extensions and community outreach such as loaning artwork and planning of art history classes outside of the museum; fundraising - planning of annual balls, trips and markets; and hospitality, including culinary events. To sustain the social life of their institution and to promote public interest, the committees diversified their educational programming and added culinary counterparts to artistic events.

The AGT became a very active culinary space after the mid-1940s, when the women's committees focused on food as a primary mode of recruiting new members and fundraising to sustain other projects, including purchasing new art for the museum's growing collection. In the AGT's early days, food was present in the museum on multiple occasions: for example, after 1926, afternoon tea was served in the Grange for a minimal cost of 25 cents; during the Second World War, 'men and women in the services' were invited to the museum for refreshments on Sundays. These smaller events, often coordinated with outside charitable organizations such as The Church Friendship League, were integrated by the women's committees into a museum-wide culinary strategy, involving partnerships with local businesses and assiduous communication with Torontonians through media partners. Beginning in 1945, the AGT became the scene of lavish annual balls, monthly lunches, afternoon tea on Sunday, and Christmas baking events. Several culinary initiatives, such as Snack Lunches, Men's Lunches and The Art of Cooking (a series of demonstrations for homemakers led by famous chefs) became citywide traditions (Mihalache 2016a). In 1948, to attract new members, the Women's Committee initiated the Snack Lunches, held on the Tuesday following each exhibition opening. After lunch, consisting of a hot casserole and green salad, cooked in the volunteers' kitchen in the Grange by members of the women's committees, and followed by croissants, patisserie and coffee, diners were invited for a tour of the exhibition. Another popular culinary initiative, the Men's Lunches, was launched in 1958 by the Junior Women's Committee with the scope of attracting to the AGT a rather difficult to engage audience, men (Mihalache 2016a). By inviting middle and upper class professionals to a home-cooked meal, accompanied by a drink and a gallery tour, committee members sought to cultivate a community of donors who would perceive the value of the museum as a space to socialize.

\section{Art Museum Eating and Domesticity: Building up a Taste for Gourmet}

In the process of developing culinary projects, the women's committees generated a set of values and expectations, anchored loosely in gourmet dining and entertaining. At the core of the culinary culture were recipes, which they selected, interpreted and adapted based on knowledge gained in the domestic space paired up with exposure to the increasingly popular home economics field (Neuhaus 2003; Shapiro 2004). Culinary knowledge co-existed at the AGT with other forms of education and artistic training which are typical of art museums. For many attending Men's Lunches, the AGT was a space for commensality and business rituals. For the domestic cooks who attended The Art of Cooking demonstrations, AGT was meaningful due to the information on new ingredients, tips for gourmet home cooking and modern kitchen gadgets, which could be observed as a form of acculturation.

The culinary culture at the AGT/AGO was based on the French-inspired gourmet ideals of the time, which were visible in the menus and cooking strategies practiced by the women's committee. Gourmet cooking and dining refers to the gastronomic milieu based on the value of good living, where cooking is a form of pleasurable artistic expression rooted in French heritage (Strauss 2011). In the United States, observed Jessamyn Neuhaus (2003: 104), the new gourmet movement which emerged in the 1940s 'advocated fresh ingredients, simplicity, and above all, reverence for food and for eating'. Chefs such as James Beard, who cooked for Toronto audiences in 1961 and 1962 at the invitation of the AGT's women's committee, called for "an appreciation of "ethnic" cuisine with authentic ingredients, the emphasis on fresh rather than processed foods, and attention to restaurant dining' (Neuhaus 2003: 105). These gourmet ideals were complicated by the realities of war shortages (Bentley 1998; Neuhaus 
2003) and by the narratives of home cooking which prevailed in North American kitchens. The food cooked by the AGT women's committee after the mid-1940s was caught in the midst of these ideological debates over gourmet dining, especially considering the context of Canada, which was slower in establishing its own national cuisine (Cooke 2009).

Beginning in the mid-1940s, when the committees launched museum dining events, they expressed their desire to offer homemade-style meals inspired by gourmet trends, cooked in the museum, and accompanied by a tour of the gallery. For example, the Men's Lunches were promoted in the Coming Events brochure (1969: 9) as follows: 'the Junior Women's Committee will serve hot, gourmet, buffet lunches in the Sculpture Court'. ${ }^{8}$ At Men's Lunches, guests could expect to be served dishes such as 'chicken. Italian style rice, Italian Garlic Bread, Green Salad, Fresh Fruit \& Cheese Tray', alongside coffee and wine ${ }^{9}$. For The Art of Cooking demonstrations, celebrity chefs from United States and England were invited to teach Torontonians gourmet recipes which could be easily cooked at home. The substantial media coverage of these events focused on narratives of gourmet entertaining (a few articles as sources), while noting the contradictions inherent in the French-inspired gourmet culinary ideal. Josée Johnson and Shyon Baumann (2007: 171) discussed the gastronomic discourse produced by gourmet food writing 'as a fluid discursive field where the legitimacy of food production and consumption methods are negotiated' and 'not as a fixed set of culinary practices'.

While a gourmet eating culture was undeniably present at the AGT through culinary events, its public form was shaped by the museum's physical space and was undeniably less class conscious. To prepare for the Snack Lunches, the women's committees required storage space in the Grange for cans and other goods. At any given time in the year, one might encounter in the museum, tins of apricots, pears and pineapple, mushroom soups and canned spaghetti. ${ }^{10}$ These might not have been the top pick for a gourmet meal, which ought to include fresh ingredients and discourage use of canned products (Neuhaus 2003), but they were part of the repertoire of ingredients which made their appearance quite often on the diners' plates. Some of the brands which were stocked in the museum were among those which a true gourmet chef would not employ - Donald Duck grapefruit sections, Miracle Whip Salad dressing, Dole sliced pineapple and Cloverleaf tuna fish ${ }^{11}$. The re-invention and re-interpretation of gourmet dishes through ready-made shortcuts - often, the dessert pastries were purchased and not homemade - became part of the cooking practices of the women's committees. Kathleen LeBesco (2001: 130) reflected on the quintessentially democratic and non-gourmet food, Jell-O, suggesting that it 'has been and continues to be used as a tool for resisting expectations about gender and social class'. This approach to thinking about food as a form of resistance to efforts at acculturation stems out of broader frameworks which position food as a form of self-expression for women. Sherrie A. Inness (2001: xiii) wrote that 'for some of these women, cooking, rather than being something that confined and limited them in the kitchen, was a way to gain personal power both in and outside of the home'.

The members of the women's committees constructed a public eating culture at the AGT which could be perceived as a successful integration of domestic skills into a gendered public setting. The use of the gourmet narrative, which was a culinary philosophy 'approved' by men and appropriate to the return of working females to the home sphere after the war ended (LeBesco 2001: 133; Hollows 2002; Hermelin, Hinchcliffe \& Stenbacka 2017) allowed women a legitimate entryway into public dining. Through the crafting of a hybrid gourmet culture anchored in domestic knowledge, the women's committees' work resisted the masculinized rituals of the art museum.

Despite resistance, their work with food perpetuated some of the biases of their class positioning. As Zancowicz (2014:9) points out, 'many of them were upper or middle class [white] women who were university educated'. This observation suggests that multiple and sometimes competing levels of privilege influenced women's committees' work in terms of which communities they served and communicated with, the values they wished to instil in museum visitors, and the aesthetics (and recipes) they favoured. However, a dismissal of their work based on such considerations - primarily white privilege - would fail to account for their attempts to adapt to changing social, cultural and political contexts, and for their assiduous efforts to connect the museum with its communities, using existing personal networks or building connections to 
new stakeholders. The numerous culinary projects, developed under a gourmet cooking and dining practice, are ideal sites to understand the complex and contested work of the women's committees, as they made sense of their own place in the museum, outside of the domestic spaces. In the process, this culinary culture opened up the possibility for the AGO's first official eating spaces: a restaurant, a cafeteria, and a new members' lounge.

\section{From Culinary Programming to the Grange Court Restaurant: Official Dining at the Art Gallery of Ontario}

The pairing of tasty food with an artistic experience was the underlying strategy of the eating practices developed at the AGT in the early days of food programming, under the guidance of the women's committees and inspired by gourmet cooking practices. The development of official eating spaces included consultations with members of the women's committees previously involved with culinary events, who were invited, in May 1972, to form a subcommittee on AGO Dining Services. Consultations took place around matters of space allocation, food selection, naming of eating spaces and staffing. In a letter to the editor sent to the Globe and Mail, Valliere Cronyn (1974), chairman of the Dining Services Committees and former Art of Cooking Chairman, explained the motivation behind the restaurant's name:

....the restaurant overlooks the Grange, the Gallery's original home. The restaurant will incorporate an actual outdoor court, now under construction, which, in effect, supplies a visual link between the buildings old and new. It will be a pleasant spot for dining in warmer months. When completed this court will contain the familiar marble fountain, Verrochio's Child with Dolphin which for so many years stood in the Walker Court of the old gallery. For these reasons, we believe the restaurant's name, Grange Court, represents an important and obvious bridge between the gallery's past and its future. ${ }^{12}$

This brief passage shows continuity between past culinary practices and the new eating spaces. For example, while the term 'gourmet' is not explicitly used in the reports submitted by the committee, the proposed foods resemble the menus put together by the women's committees. A 1972 report suggested that the restaurant serve 'made-to-order sandwiches (not pre-wrapped), a good soup, possibly salads with choice of ingredients, French bread, hot dish such as roast beef carved on the spot, or Quiche Loraine - good food with a flair but not elaborate choice or charge'. ${ }^{13}$ The post-1974 eating spaces at the AGO were rooted in culinary practices that would have been familiar to AGO members and visitors but simultaneously had to distance themselves from this culinary heritage to satisfy the AGO's promise of newness and reinvention. While behind-the-scenes, members of the women's committees were part of the advisory groups formed to make decisions about the format of the new restaurant, once the AGO hired a professional culinary team, the womens' roles decreased significantly.

The transition from an informal culinary infrastructure to an official culinary framework happened as the museum was going through the first major renovations (Stage I) in its recent history, made possible by a large Ontario government grant intended for building expansion. In 1974, the AGO reopened to the public with not only one, but three food spaces - the Grange Court Restaurant, the Cafeteria and the Members' Lounge. The naming of eating spaces denotes a hierarchy of intended audiences. William Winthrow, AGO director at the time, stated that 'a restaurant is really necessary in a place like the gallery since it will allow us to serve the whole person rather than just the eyes. It will give a much needed place to relax during visits to the gallery which often can be pretty intense affairs'14. The opening of Grange Court was presented as a further step in making the AGO a cultural centre which could compete with similar institutions. Newspaper articles covering the opening of the new AGO pointed out that 'the amenities are impressive. There is a delightful restaurant (with liquor license), a cafeteria, members' lounge, rest area for the weary, a gift shop and a book shop'15.

The creation of the three new eating spaces in 1974, managed by the newly established Dining Services department, resulted in the hiring of a culinary team and an increase in communication about the museum's culinary offerings attached to the new spaces of food consumption. The existence of Grange Court Restaurant opened up a new culinary discourse 
based on cooking as a professional rather than a leisurely activity. The presence of a chef in the museum meant that the committee members would no longer need to cook for visitors and members, with some exceptions, as the Grange was still functioning as a historic house and a site for catered events, dinners and lunch talks. The recipe collections, lists of ingredients and notes used for culinary events by the women's committees were replaced with formal restaurant menus, which reimagined the taste preferences of the visitors.

Culinary programs such as Men's Lunches and Snack Lunches were terminated and replaced with other programming - Dinner for Beginners, Art in the Morning and Artful Dining, all located in the Grange Court Restaurant or the Members' Lounge. The gourmet homemade dining culture which was crafted and developed by the women's community was replaced with a new type of high dining, based on the (male) chef's culinary experience and knowledge. For example, the Movie and Dinner program offered to members was promoted in the November/December 1976 Events through its menu, 'prepared by the Gallery's chef' and featuring 'Consommé Poires Frites; Cornish hen stuffed with wild rice; Grilled tomato, broccoli; Spinach, Belgium endives, mushroom salad; Crème de menthe parfait; Coffee or tea and a glass of wine'. The Summer 1977 menus for Dinner for Beginners, a popular event consisting of dinner in Grange Court, a themed tour of the gallery, followed by coffee in the Members' Lounge, were loosely inspired by the topic of the event. For example, the Dutch cityscape menu featured 'mixed green salad; pot roast jardinière; boiled potatoes; fresh fruit salad; coffee or tea', while the Canadian contemporary art menu included deep-fried sole fillet with tartare sauce and crème caramel.

From 1974 until 2002, when Transformation AGO brought new eating spaces to the museum, Grange Court Restaurant, the cafeteria and the members' lounge struggled to retain guests, striving to provide a menu that was elegant and affordable which could be fully integrated into the museum's activities. These struggles were 'recorded' in the internal communication between the Dining Services team and other AGO departments, where topics of access, promotion strategies, visitor satisfaction or price increases of coffee were discussed. Different menu design strategies were tested by the various chefs who ran the AGO kitchens, leaving legacies which can be observed in today's bistro. For example, the themed menu as a genre was introduced in Grange Court Restaurant in the early 1980s, when The German Masters on the Nineteenth Century exhibition was accompanied by German-inspired dishes such as 'herring fillet in sour cream, with apples and onions', 'beef rolls with red cabbage and potatoes' and 'German apple cake' (Menu 07/81, personal collection). Starting around the same time, the restaurant's menus become more and more international (European) in scope, featuring dishes such as Hot Borscht, Greek salad, and Tortellini (Menu 11/82, personal collection). The diversification of the menu through the integration of new food trends and international dishes paved the way for the 'global bistro cuisine' of more recent efforts.

In 2002, the AGO entered another renovation and expansion project, Transformation AGO, which resulted in a building designed by Frank Gehry, promising to be 'a social space that would be both exciting and welcoming' (Milrod 2008: 4) ${ }^{16}$. Part of Transformation AGO was the reinvention of the museum's culinary spaces with the addition of a spectacular restaurant, FRANK (after Gehry), featuring global bistro cuisine with exhibition-inspired thematic menus (Mihalache 2016b). In a competitive art museum global scene, the current restaurant acts as a site of class differentiation, ensuring that Toronto's largest art gallery participates in a glamorous and exclusive restaurant culture. The modernist décor, the high cuisine menu and the prices are prohibitive to and unwelcoming for many museumgoers. In the AGO's case, the more visible the eating spaces became, the more distanced they were from the women's committees' attempts to democratize the museum. In August 2017, FRANK was rebranded as AGO Bistro, restating its commitment to 'local seasonal fare and quality fresh ingredients' 17 . In addition, AGO includes CaféAGO, located on the lower concourse of the museum, offering 'AGO visitors rest and refreshment in a relaxed and congenial environment' ${ }^{18}$; an Espresso Bar in Galleria Italia, one of the highlights of the Gehry-designed building, where visitors can pause and 'experience a picturesque view of Toronto while enjoying a beverage and tasty treat'19; and the Norma Ridley Members' Lounge which was relocated to the Grange to provide 'a relaxing haven during visits to the Gallery' ${ }^{20}$. The more affordable CaféAGO located in the museum's basement denotes a hierarchy of eating spaces, with the museum's primary focus 
being on the AGO Bistro, located in prime space near the museum's entrance, visible from the street and prominently present on the AGO's website.

\section{Conclusions: Lessons from a Museum's Culinary History}

\section{Volunteer Women in Art Museums: The Messy Elitism of Food Programming}

In the 1940s, the women's committees hoped to open the museum's doors to a diversity of audiences, from the wealthy male financier to the 'common Canadian'. Food was seen as a tool to extend the museum's relevance beyond its primary functions - collecting and display. However, as this article has shown, culinary programming at the AGT/AGO did not always manage to democratize the institution, as events such as Men's Lunches targeted upper class men; Art of Cooking invited celebrity chefs with gourmet sensibilities; and women's committee members were middle and upper class white women with leisure time on their hands. At the same time, bringing food inside the museum outside an established restaurant required the transformation of the museum's space. In this context, women's import of domestic knowledge and skills into the museum acted as a form of resistance which validated the home kitchen as a space for learning, experimentation and creativity. Besides raising the museum's profile, cultivating a loyal membership, and developing initiatives which are still in place today (e.g. the Extensions Department, the Art Rental program, the shop), the women's committee made a place for women in the public sphere. Even if the women often came from a privileged background, they showed a good understanding of women's needs and hurdles in a changing city. Within the limitations of their backgrounds, they revisited their own biases, and, while not always acting on these reflections, they showed just how 'messy' the democratization of an elitist institution can be.

\section{The Art Museum Restaurant: Nouveau Elitism?}

The connections that women's committees at the AGO made with different communities of visitors were challenged by the introduction of official eating spaces in the early 1970s. Women's committees were consulted in the search for a smooth transition but in the end their role in the museum's culinary life was decreased considerably. The culinary teams helmed by professional male chefs (although a professional female chef now heads the bistro) designed new eating experiences which merged trendy dishes and ingredients with the existing culinary presence. However, the legacy of women's committees' work with food has been completely lost today, when AGO Bistro makes claims to culinary tropes - local, fresh ingredients - which are anchored more in a flashy trendiness than a desire to appeal to a wide range of visitors. What women's committees in the past interpreted as gourmet was in fact a hybrid negotiation between what was modern and desirable and what was doable in terms of access to ingredients. The primary scope of culinary programming was to lure people inside the museum with food in the hopes that they would come back as repeat visitors or members. AGO Bistro is quite a contrary example, as it translates the museum's identity into intentionally sophisticated dishes such as Fried Panela (salsa rojo, nopales and sweet pepper, bitter greens) and Birria-Braised Beef (hominy grits, roasted tomatillo, avocado crema) ${ }^{21}$. Eating at AGO Bistro is an opportunity for social differentiation for diners and often it is not accompanied by a visit to the museum. Eating in art museums as a new genre of public dining may render the museum secondary to the restaurant (Mihalache forthcoming 2017).

\section{Art Museums' Culinary Life: Why Explore Food in Museums}

The AGO's food history demonstrates the significance of culinary programming and dining out opportunities for the museum's outreach and sociability. To observe the museum as process (McTavish 2013) and as a real rather than theoretically constructed institution (Rice 2003), it is imperative to bring into conversation all aspects of its cultural production and the communities that develop, maintain and challenge its practices. A focus on food shows the museum's efforts in building connections with local stakeholders, and sometimes inadvertently intervening in 
the culinary life of the city. This article advocates for the remaking of art museums' histories to account for these complicated and messy initiatives which expressed, through food, their concerns for museums' lack of relevance. A focus on food can extend the conversation to other areas which were covered by women's committees, who actively looked outside the museum and the city centre for new museum visitors and members. Likewise, a look at restaurants demonstrates the difficulty in overcoming instances of elitism inside the art museums despite food's potential for democratic interventions and increased access.

Received: 25 April 2017

Finally accepted: 5 January 2018

\section{Notes}

1 Severson, K. (March 29, 2006) 'Go for the van Gogh, But Stay for the Smoked Eel with Jalapeno', New York Times http://www.nytimes.com/ 2006/03/29/arts/artsspecial/go-forthe-van-gogh-but-stay-for-the-smoked-eel-with.html, accessed March 24, 2017.

2 Post, S. (June 13, 2014) ‘Table d'hote and à la carte: A Museum's Restaurants http://www. metmuseum.org/blogs/digital-underground/ 2014/museum-restaurants, accessed March 24, 2017.

3 Special issue with a section on "Food in the Museum", Museum (2015), 94 (May/June) 36-53.

4 The Art Gallery of Toronto (AGT) was re-named the Art Gallery of Ontario in 1966. As this article makes reference to various moments in the institution's history, spanning over a century, it will utilize AGT to refer to the pre-1966 period and AGO to the post-1966 period.

5 The Art Gallery of Toronto Bulletin (November 1926), Reference Cabinet, AGO Library and Archives.

6 Wees F.S. (April 1, 1949) 'A History of the Public Relations Project in the Art Gallery of Toronto from April 1st, 1949', AGO Library and Archives.

7 Fell C.P. (1948) Mrs. C. P. Fell to Mrs. Graham Morrow, Letter, Women's Committee Archives, AGO Library and Archives.

8 Coming Events (Jan-Apr 1969), Reference Cabinet, AGO Library and Archives.

9 Smiter J.M. (October 20, 1966), Press Release for Men's Lunch event, Women's Committee Archives, AGO Library and Archives.

10 'Stock on hand after April 27, 1953', Women's Committee Archives, AGO Library and Archives.

11 'Food Order for Stock, 1952-1953', Women's Committee Archives, AGO Library and Archives.

12 Cronyn, V. (October 22, 1974) 'Courtly Dining' Letters to the Editor, Globe and Mail.

13 'Report of the AGO Dining Facilities Sub-Committee to the Building Committee' (September 22, 1972), AGO Library and Archives.

14 'ROM, Art Gallery to get Building Grants' (February 15, 1971), Globe and Mail, 5.

15 Cameron, D. (October 19, 1974) 'The Coming of Age of the Art Gallery of Ontario', Globe and Mail. 
16 Milrod, L. (2008) 'New Building. New Ideas. New Art. New Spaces', Art Matters 16 (4) 4-5.

17 'AGO Bistro', http://ago.ca/shop-dine/ago-bistro, accessed September 20, 2017.

18 'CafeAGO', http://www.ago.net/cafe, accessed March 20, 2017.

19 'Espresso Bar in Galeria Italia', http://www.ago.net/espresso-bar-in-galleria-italia, accessed March 20, 2017.

20 'Norma Ridley Members Lounge', http://www.ago.net/norma-ridley-members-lounge, accessed March 20, 2017.

21 'Prix Fixe', https://ago.ca/shop-dine/ago-bistro/prix-fixe-lunch-and-dinner-menu, accessed September 20, 2017.

\section{References}

Barnes D. R. and Peters G. R. (2002) Matters of Taste: Food and Drink in Seventh Century Dutch Art and Life, Syracuse: Syracuse University Press.

Bennett, T. (1995). The Birth of the Museum: History, Theory, Politics, London: Routledge.

(2006) 'Civic Seeing: Museums and the Organization of Vision', in Sharon Macdonald (ed), A Companion to Museum Studies, 263-281, Malden: Blackwell Publishing.

(2015) 'Thinking (with) Museums: From Exhibitionary Complex to Governmental Assemblage, in Kylie Message and Andrea Witcomb (eds), 3-20, Museum Theory, London: Wiley.

Bentley, A. (1998). Eating for Victory: Food Rationing and the Politics of Domesticity, Urbana: University of Illinois Press.

Beriss, D. and Sutton, D. (2007) 'Restaurants, Ideal Postmodern Institutions', in David Beriss and David Sutton (eds), The Restaurants Book: Ethnographies of Where We Eat, 1-13, Oxford: Berg.

Bottinelli, S. and Valva M. d'A. (eds) (2017 forthcoming) The Taste of Art: Cooking, Food and Counterculture in Contemporary Practices, Fayetteville: The University of Arkansas Press.

Bourdieu, P. (1979[1984]) Distinction: A Social Critique of the Judgement of Taste, translated by Richard Nice, Cambridge: Harvard University Press.

Classen, C. (2007) 'Museum Manners: The Sensory Life of the Early Museum', Journal of Social History, 40 (4), 895-914.

(2014) A Cultural History of the Senses in the Age of Empire 1800-1920, London: Bloomsbury Academic.

Cooke, N. (ed) (2009). What's to Eat? Entrees in Canadian Food History, Montreal \& Kingston: McGill-Queen's University Press.

Douglas, M. (1972) ‘Deciphering a Meal', Daedalus, 101 (1), 61-81.

(1984) Food in the Social Order, New York: Russell Stage Foundation.

Duncan, C. (1995) Civilizing Rituals: Inside Public Art Museums, London: Routledge. 
Elliott, C. (ed) (2016) How Canadians Communicate about Food: Food Promotion, Consumption and Controversy, Edmonton: Athabasca University Press.

Erby, K. (2016) Restaurant Republic: The Rise of Public Dining in Boston, Minneapolis: University of Minnesota Press.

Finkelstein, J. (1989) Dining Out: A Sociology of Modern Manners, Oxford: Polity. (2014) Restaurants and the Making of Modern Identity: Fashioning Appetite, London: I.B. Taurus.

Helly, D. O. and Reverby, S. M. (eds) (1992) Gendered Domains: Rethinking Public and Private in Women's History, Ithaca: Cornell University Press.

Hermelin, B., Hinchcliffe, G. and Stenbacka, S. (2017) 'The Making of the Gourmet Restaurateur - Masculine Ideology, Identity and Performance', Norma: International Journal for Masculinity Studies, 12 (1), 48-64.

Hollows, J. (2002) 'The Bachelor Dinner: Masculinity, Class and Cooking in Playboy, 195361', Continuum, $16(2), 143-155$.

Howes, D. (2004) Empire of the Senses: The Sensual Culture Reader, London: Berg.

Inness, S.A (ed) (2001) Cooking Lessons: The Politics of Gender and Food, Lanham: Rowan \& Littlefield.

Jacobs, M. and Scholliers, P. (2003) Eating Out in Europe: Picnics, Gourmet Dining and Snacks since the Late Eighteenth Century, London: Bloomsbury Academics.

Johnston J. and Baumann, (2007) 'Democracy versus Distinction: Omnivorousness in Gourmet Food Writing', American Journal of Sociology, 113 (1) 165-204.

Kaufman, A. and Lorway, C. (2012) 'Integrating Social Spaces', in Barry Lord, Gail Dexter Lord and Lindsay Martin (eds), Manual of Museum Planning: Sustainable Space, Facilities and Operations, 121-139, Lanham: Altamira Press.

LeBesco, K. (2001) 'There's Always Room for Resistance: Jell-O, Gender, and Social Class', in Sheries A. Inness (ed), Cooking Lessons: The Politics of Gender and Food, 129-149, Lanham: Rowan \& Littlefield.

Levent, N. and Pascual-Leone A. (2014) The Multisensory Museum: Cross-Disciplinary Perspectives on Touch, Smell, Memory and Space, Lanham: Rowan \& Littlefield.

Levent, N. and Mihalache, I.D. (2016) Food and Museums, London: Bloomsbury.

Malaguzzi, S. (2008). Food and Feasting in Art, Los Angeles: Getty Publications.

McClellan, A. (ed) (2003) Art and Its Publics: Museum Studies at the Millennium, London: Wiley-Blackwell.

(ed) (2008) The Art Museum from Boullée to Bilbao, Berkeley, CA: University of California Press.

Mihalache, I. D. (2016a) 'A Museum's Culinary Life: Women's Committees and Food at The Art Gallery of Ontario', Global Food History, 2 (2), 157-178.

(2016b) 'Critical Eating: Tasting Museum Stories on Restaurant Menus', Food, Culture \& Society, 19 (2), 317-336.

(forthcoming 2017) 'A Cultural History of Restaurants in Art Museums: Creative 
Collaborations', in Kathleen LeBesco and Peter Naccarato (eds) Handbook of Food and Popular Culture, London: Bloomsbury.

Neuhaus, J. (2003) Manly Meals and Mom's Home Cooking: Cookbooks and Gender in Modern America, Baltimore: Johns Hopkins University Press.

Pillsbury, R. (1990) From Boarding House to Bistro: The American Restaurant Then and Now, Boston: Unwin Hyman.

Ray, K. (2016) The Ethnic Restaurateur, London: Bloomsbury.

Rice, D. (2003) 'Museums: Theory, Practice and Illusion', in Andrew McClellan (ed) Art and Its Publics: Museum Studies at the Millennium, 77-95, Malden, MA: Blackwell.

Shapiro, L. (2004) Something from the Oven: Reinventing Dinner in 1950s America, New York: Penguin Books.

Silverman, R. (2015) Museum as Process: Translating Local and Global Knowledge, London: Routledge.

Spang, R. (2001) The Invention of the Restaurant: Paris and Modern Gastronomic Culture, Cambridge: Harvard University Press.

Strauss. D. (2011) Setting the Table for Julia Child: Gourmet Dining in America, 1934-1961, Baltimore: Johns Hopkins University Press.

Sylvester, C. (2009) Art/Museums: International Relations Where We Least Expect It, London: Routledge.

Walker, H. (ed) (1999) Food in the Arts: Proceedings of the Oxford Symposium on Food and Cookery, Devon: Prospect Books.

Warde, A. (2016) The Practice of Eating, Oxford: Polity.

Zancowicz, K. (2014) In Her Hands: Women's Educational Work at the Royal Ontario Museum, Canadian National Exhibition, and Art Gallery of Toronto, 1900s-1950s, Thesis (PhD), University of Toronto.

*Irina D. Mihalache is an assistant professor of Museum Studies at the Faculty of Information, University of Toronto. Her academic background in communication and cultural studies, paired with her interest in food studies, has developed into a research agenda which inquires about the intersections between food and museums. On this topic, she co-edited a book, Food and Museums (November 2016, Bloomsbury Academic). She wrote several book chapters on museum restaurants and museum interpretation, on restaurants in French post-colonial museums, and on culinary programming organized by the volunteer committees at the Art Gallery of Ontario in the period from 1940 to 1970.

Irina D. Mihalache, Assistant Professor,

Faculty of Information

University of Toronto

140 St. George Street

Toronto ON M5S $3 G 6$

Canada

Email: irina.mihalache@utoronto.ca

Tel: (416) 946-5364 